the Union urges the continued publication of the Belgrade Annuaire, which contains the apparent places of 240 stars not appearing in any other ephemeris, until such time as the apparent places of all fundamental stars are published in a single volume." This was carried unanimously.

Dr Comrie, referring to the 7 - and 8-figure tables prepared by Prof. Peters and himself, said that it was difficult to obtain the $£ 5000$ necessary for their printing, or even a smaller sum for subsidised publication. In reply to a question by Prof. Banachiewicz as to why six functions were not proposed, he said that each volume of four functions would run to more than 900 pages, and that a larger volume would be unwieldy. Dr Robertson moved, and it was carried unanimously, that the General Assembly be asked to adopt the following resolution: "That this Union considers early publication of the 7-and 8-figure tables of the four principal trigonometrical functions for every second of arc prepared by Prof. Peters and Dr Comrie to be highly desirable in the interests of science generally."

A proposal from Dr Smiley that the Commission should fix the value of the Gaussian constant $k$ was discussed. No ambiguity exists if not more than eight or nine significant figures are required, but conflict arises between the various natural and logarithmic values if ten or more significant figures are required. On the motion of Prof. Brown the President was asked to consult people known to be interested, and to report at the next meeting of the Union.

\title{
COMMISSION 5. (BIBLIOGRAPHY.)
}

\author{
President: M. P. Stroobant \\ SECRETARY: M. P. BoURgeoIS \\ Edition d'anciennes observations et de traductions de classiques \\ astronomiques (Almageste, Kopernikus, etc....)
}

M. Stroobant estime que les questions soulevées à ce sujet par MM. Dittrich, Brasch et Pogo sont du ressort de la Commission 2; cette Commission devant les difficultés matérielles que présentait pareille entreprise sous les auspices de I'U.A.I. a cessé son activité au Congrès de Rome (Ig22).

M. Lundmark estime que la question est importante, qu'il convient que l'U.A.I. s'y intéresse et que la Commission s'en occupe.

M. Collinder considère, d'expérience personnelle, que parfois, tout au moins en ce qui concerne certains ouvrages anciens importants au point de vue historique, une publication partielle serait suffisante.

La Commission décide de charger une sous-commission formée de MM. Stroobant, Brasch, Dittrich et Pogo de l'étude de la chose et particulièrement de la question des voies et moyens.

\section{Bibliographies}

A l'unanimité la Commission adopte la motion d'approbation proposée par M. Grouiller concernant la Bibliographie Mensuelle de l'Astronomie et figurant dans le rapport. Elle décide de soumettre à l'Assemblée Générale la résolution suivante: "Etant donné l'intérêt que présente la publication rapide de renseignements d'ordre bibliographique la Commission 5 demande à l'unanimité qu'une subvention de $£$ IOo soit attribuée à la Bibliographie Mensuelle de l'Astronomie." 
Au sujet de la publication des "Bibliographies" sur une seule face des feuillets, M. de la Baume Pluvinel estime qu'en ce qui regarde la Bibliographie Mensuelle de l'Astronomie des questions budgétaires rendent la chose difficile; il suggère que vu le cout peu élevé de cette publication les personnes qui désirent former un fichier y souscrivent deux abonnements. La question du format retiendra l'attention du Comité Directeur de cette revue bibliographique.

La Commission estime intéressant que la bibliographie soit étendue à certaines publications s'occupant de l'histoire des sciences et en particulier à la revue Isis.

Elle marque son accord de principe à la suggestion de M. Donald H. Menzel, transmise par M. Shapley:

"To make accessible to astrophysicists physical investigations from physical and chemical journals in all languages. The various physical publications are numerous, and the languages are so diversified that many investigations of astrophysical importance undoubtedly escape the attention of even the most alert astrophysicist. By cooperative effort of the various members of the Commission, who would be assigned the duty of reporting on specific journals, a bibliography of current research in physics could be formed. The abstract, if any, would be subsidiary to those given in Science Abstracts, etc...., and would point out only the facts of astrophysical importance that are not suggested by the title itself."

M. de la Baume Pluvinel déclare qu'un effort dans ce sens sera tenté par la Bibliographie Mensuelle de l'Astronomie. MM. Baldet et d'Azambuja, reconnaissant l'intérêt de cette suggestion, signalent l'importance qu'il y a selon eux à rester dans un cadre bien défini.

Pour faciliter le travail des collaborateurs de la Bibliographie Mensuelle de l'Astronomie et assurer un dépouillement complet des publications des différents observatoires, la Commission suggère que ces derniers sur les indications du Comité Directeur de la revue fassent le service de leurs publications aux personnes chargées de les dépouiller.

\title{
COMMISSION 6. (TELEGRAMS.)
}

\author{
President: Prof. E. Strömgren \\ SeCretary: Miss J. M. Vinter Hansen.
}

At its meeting the Commission adopted the cipher code for astronomical telegrams, proposed by the President, with two minor alterations, and agreed that the new code was to be used from I935 Nov. I. The corrected cipher code is given below in this volume (p. 39I).

The Commission also asked for an annual grant of 1200 Swiss francs to the Bureau of Astronomical Telegrams until the next meeting of the Union.

(A joint discussion with Commission 20 is reported by the latter Commission. p. 309.) 